\title{
Progressive subretinal fibrosis and multifocal granulomatous chorioretinitis
}

\author{
Fibrose sub-retiniana progressiva ecorioretinite granulomatosa multifocal
}

\author{
Miguel Hage Amaro ${ }^{1}$ \\ Cristina Muccioli ${ }^{2}$ \\ Mario Martins dos Santos Motta ${ }^{3}$
}

${ }^{1}$ MD. Department of Ophthalmology, Universidade Federal de São Paulo - UNIFESP - São Paulo (SP) - Brasil.

${ }^{2}$ MD. Department of Ophthalmology, UNIFESP - São Paulo (SP) - Brasil.

MD. Department of Ophthalmology, Universidade do Rio de Janeiro - UniRio - Rio de Janeiro (RJ) - Brasil.

Corresponding Author: Miguel Hage Amaro - Address: Quintino Bocaiuva, 516 - Belém (PA) CEP 66053-240

E-mail: amaro@amazon.com.br

Recebido para publicação em 23.08.2005

Versão revisada recebida em 02.12.2005

Aprovação em 11.01.2006

Nota Editorial: Depois de concluída a análise do artigo sob sigilo editorial e com a anuência do Dr. Nelson Alexandre Sabrosa sobre a divulgação de seu nome como revisor, agradecemos sua participação neste processo.

\section{ABSTRACT}

We describe a case of progressive subretinal fibrosis and multifocal chorioretinitis along with its findings on both fluorescein and indocyanine green angiography. The progressive subretinal fibrosis syndrome is a severe subset of multifocal choroiditis. The clustering of lesions around the nerve optic head may mean that the disease is spread through the flow in and out of the eye around the optic nerve.

Keywords: Fibrosis/diagnosis; Retinal diseases; Choroiditis; Chorioretinitis/diagnosis; Case reports [Publication type]

\section{INTRODUCTION}

Progressive subretinal fibrosis and blindness associated with multifocal granulomatous chorioretinitis is a rare disease initially described by Gass et $\mathrm{al}^{1}$.

The disease presents with no gender predilection, occurs in old patients and was related to previous intraocular surgery ${ }^{(1-2)}$. The first report in the literature presented a case secondary to intraocular inflammation without previous history of intraocular surgery ${ }^{(1)}$.

There is no systemic association with eye disease but the literature reports a biopsy-proved systemic sarcoidosis case with a massive subretinal fibrosis ${ }^{(3)}$

\section{CASE REPORT}

A 64-year-old man complained of progressive loss of vision in his left eye. He also reported an old severe total retinal detachment in the right eye which was never submitted to surgery.

Visual acuity was light perception in the righ eye and 20/400 in left eye.

Fundoscopy (Figure 1) disclosed a ring of elevated subretinal fibrosis tissue surrounding the optic nerve head and multifocal chorioretinitis lesions in the left eye.

Fluorescein angiography (Figure 2) showed both the ring of peripapillary fibrosis and the surrounding choroidal lesions that were hypofluorescent in the early phase and hyperfluorescent in the late phase. Indocyanine green angiography (Figure 3) disclosed multiple hypofluorescent spots of different sizes. Some of the lesions corresponded to choroidal lesions that were visible on fundoscopy but some were present beneath what looked to be a clinically normal retina.

The patient was treated with intraocular triamcinolone acetonide $40 \mathrm{mg}$ (4 mg/0.1ml), oral prednisone $60 \mathrm{mg} /$ day and oral cyclophosphamide $2 \mathrm{mg} / \mathrm{kg} /$ day, for one year. Vision acuity was hand movements after one year of treatment. 


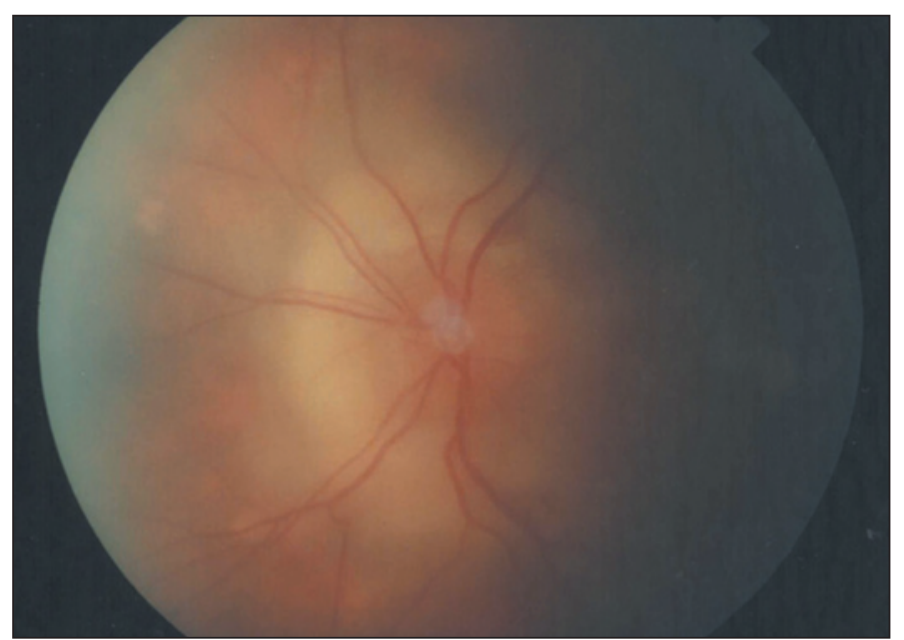

Figure 1 - Fundus photography showing peripapillary fibrosis and surrounding multifocal lesions

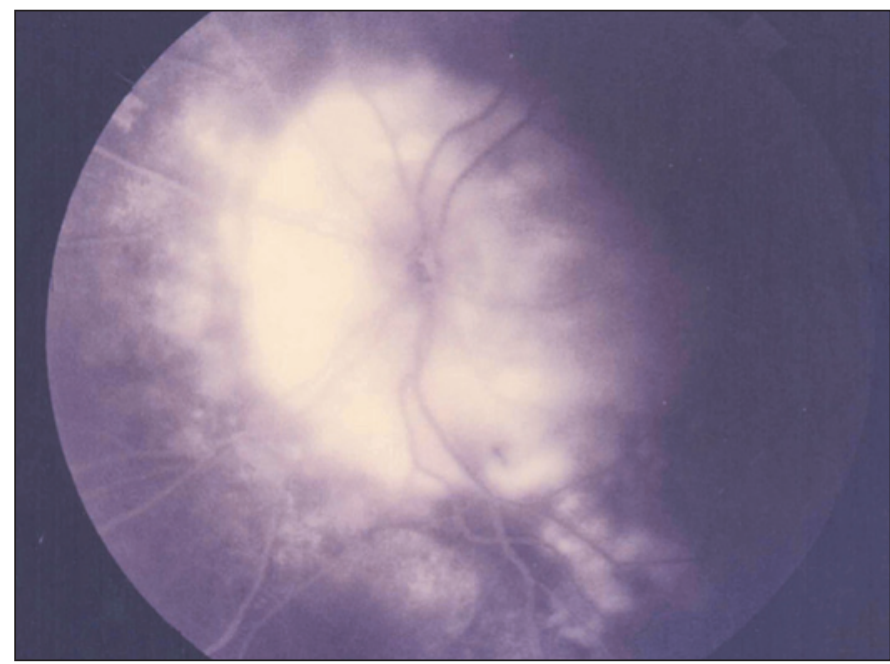

Figure 2 - Late phase fluorescein angiogram showing hyperfluorescence of fibrosis and multifocal lesions

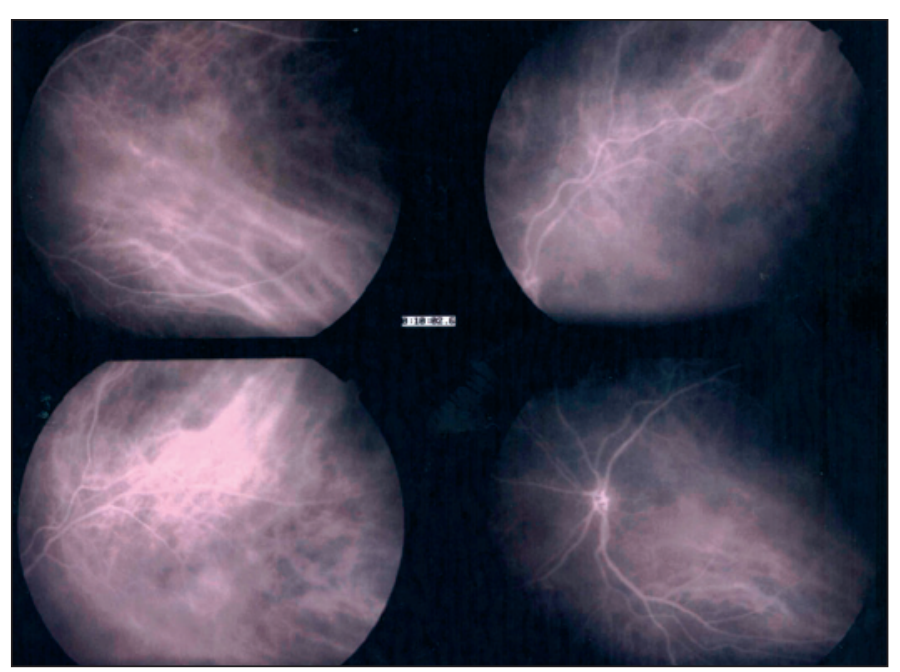

Figure 3 - Indocyanine green angiography showing numerous hypofluorescent spots in choroid

\section{DISCUSSION}

Gass and associates ${ }^{(1)}$ described three healthy elderly patients who developed severe visual loss only partly explained by multifocal chorioretinitis and massive subretinal fibrosis. Histopathologic examination of four eyes from these patients disclosed widespread destruction of the outer retina and retinal pigment epithelium, massive areas of subretinal fibrous tissue proliferation, granulomatous inflammation centered around degenerated and fragmented Bruch's membrane and chronic uveitis excluded sympathetic ophthalmia (SO).

No infectious organisms were identified by special stains or electron microscopy. Their immunohistopathologic findings and conclusions concerning the pathogenesis of the disorder were similar to those of Palestine and asociates ${ }^{(4)}$ and Kim and associates ${ }^{(5)}$.

Sympathetic ophthalmia can have only similar clinical findings regarding this patient but there was no history of trauma or surgery to either eye. Therefore this diagnosis is unlikely.

Massive subretinal fibrosis developed bilaterally in a patient with biopsy-proven systemic sarcoidosis ${ }^{(3)}$ but as Gass patients, the diagnosis of ocular sarcoid cannot be absolutely excluded in our patient because it is a form of idiopathic granulomatous inflammation.

Our patient has typical findings of the progressive subretinal fibrosis syndrome as described by Cantrill and Folk ${ }^{(6)}$ and others $^{(7-8)}$, which may be a severe variant of multifocal choroiditis.

We do not know if retinal detachment in the other eye had any effect on the disease. We wonder though if the retinal detachment in the blind eye began as severe inflammation with scarring.

It is also interesting that the lesions in this patient, as well as in other patients that are reported in the literature, cluster around the optic nerve head. This may suggest that the disease is spread through the flow around the optic nerve head. Further studies will be required to support this hypothesis.

\section{RESUMO}

Descrevemos um caso de fibrose sub-retiniana progressiva e corrioretinite multifocal granulomatosa junto com os achados de angiografia fluoresceínica e com indocianina verde e propomos uma nova fisiopatologia para a fibrose em anel justapapilar. A síndrome de fibrose sub-retiniana progressiva é uma doença grave, rara e constitui um subtipo grave da coroidite multifocal. As múltiplas lesões com fibrose circundando o disco óptico podem significar que a doença é oriunda do fluxo do líquido céfalo-raqueano, ao redor do nervo óptico.

Descritores: Fibrose/diagnóstico; Doenças retinianas; Coroidite; Coriorretinite/diagnóstico; Relatos de casos [Tipos de publicação] 


\section{REFERENCES}

1. Gass JD, Margo CE, Levy MH. Progressive subretinal fibrosis and blindness in patients with multifocal granulomatous chorioretinitis. Am J Ophthalmol. 1996; 122(1):76-85

2. Wang RC, Zamir E, Dugel PU, Sipperley JO, Thirkill CE, Shabatian B, Rao NA. Progressive subretinal fibrosis and blindness associated with multifocal granulomatous chorioretinitis: A variant of sympathetic ophthalmia. Ophthalmology. 2002;109(8):1527-31.

3. Gass JDM. Stereoscopic atlas of macular diseases: diagnosis and treatment. $3^{\text {rd }}$ ed. St. Louis: Mosby;1987. p.146-7.

4. Palestine AG, Nussenblatt RB, Chan CC, Hooks JJ, Friedman L, Kuwabara T. Histopathology of the subretinal fibrosis and uveitis syndrome. Ophthalmology. 1985;92(6):838-44.

5. Kim MK, Chan CC, Belfort R Jr, Farah M, Burnier MP, Nussenblatt RB, et al. Histopathologic and immunohistopathologic features of subretinal fibrosis and uveitis syndrome. Am J Ophthalmol. 1987;104(1):15-23.

6. Cantrill HL, Folk JC. Multifocal choroiditis associated with progressive subretinal fibrosis. Am J Ophthalmol. 1986;101(2):170-80.

7. Dreyer RF, Gass DJ. Multifocal choroiditis and panuveitis. A syndrome that mimics ocular histoplasmosis. Arch Ophthalmol. 1984;102(12):1776-84.

8. Palestine AG, Nussenblatt RB, Parver LM, Knox DL. Progressive subretinal fibrosis and uveitis. Br J Ophthalmol. 1984;68(9):667-73.

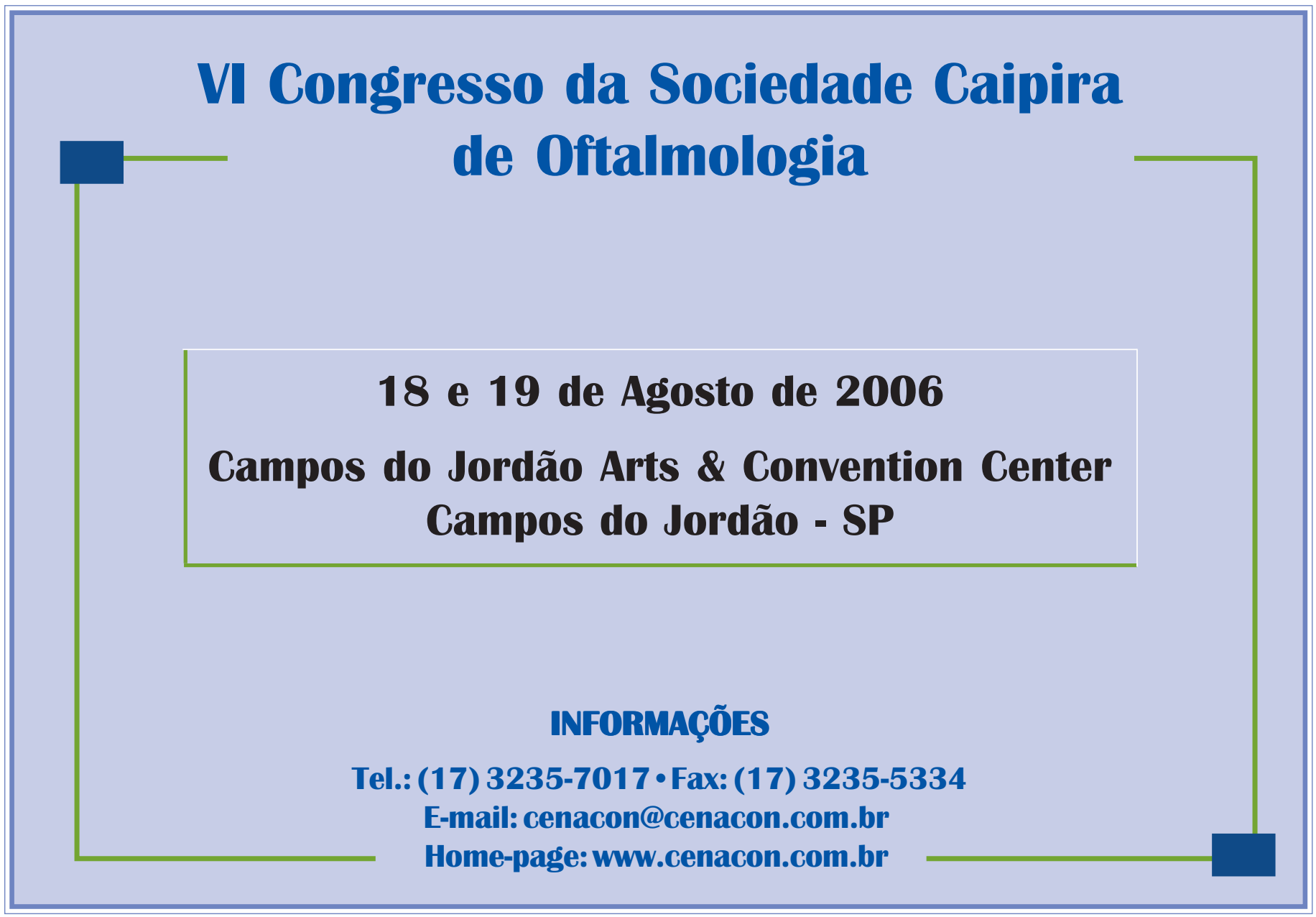

